CrossMark
Content list available at: www.benthamopen.com/TOCIEJ/
DOI: $10.2174 / 1874149501812010290,2018,12,290-300$

RESEARCH ARTICLE

\title{
Coupled Analysis of Leachate Recirculation and Heat Transfer for a Landfill with Buried Waste Tyres
}

\author{
Huijie Zhang*, Zequan Li, Haixia Xu, Xinqian Guo, Huiling Wu and Junyi Sun \\ Faculty of Civil Engineering and Mechanics, Jiangsu University, No. 301 Xuefu Road Zhenjiang, Jiangsu, 212013, \\ China
}

Received: March 21, 2018

Revised: September 9, 2018

Accepted: September 12, 2018

\begin{abstract}
:
Background:

In bio-reactor landfills, both moisture and temperature have a significant impact on the bio-degradation processes. In order to speed up the leachate recirculation, a new drainage system is proposed to build a space network of bonded whole waste tyres in landfills.
\end{abstract}

\section{Objective:}

In this study, a coupled dual-permeability flow and the heat transfer model was constructed to study the interaction between leachate migration and temperature evolution.

\section{Results and Conclusion:}

The established model was applied to a simplified bio-reactor landfill and the simulation results demonstrated that the presence of waste tyres could significantly speed up the heat transfer. And the intermittent injection and the varying injection pressure might affect the distribution of temperature as well. Additionally, cooling the leachate injected could be another measure in avoiding the occurrence of hot spots in landfills.

Keywords: Bioreactor landfill, Leachate recirculation, Bonded waste tyres, Temperature distribution, Cooling, Bio-degradation processes.

\section{INTRODUCTION}

In recent years, bioreactor landfills have become an innovative and efficacious means for the safe disposal of Municipal Solid Waste (MSW) and biogas harvesting [1, 2]. The biogas production is influenced by water content, temperature, $\mathrm{pH}$, and other factors, e.g., availability of oxygen, alkalinity, nutrients and inhibitors [3]. In bioreactor landfills, the collected leachate is recycled into municipal solid waste, eventually increasing the water content and accelerating the biodegradation of municipal solid waste [4 - 9]. In the presence of recirculated leachate, $\mathrm{pH}$ tends to remain stable probably because the injected leachate serves as a buffer solution; whereas, $\mathrm{pH}$ of the landfill without leachate recirculation declines too much below neutrality which inhibits biodegradation after a certain period [10]. The field data has proved the more rapid degradation and distinctly higher proportion of methane of the landfill with leachate recirculation compared with those without recirculation [11]. Furthermore, leachate recirculation can maximize the efficiency and waste volume reduction rate of landfill sites [12]. However, the leachate should be recirculated to all part of landfills by the employment of a recirculation system, because non-uniform distribution could result in shortcircuiting which could reduce gas production rate [13].

\footnotetext{
* Address correspondence to this author at the Faculty of Civil Engineering and Mechanics, Jiangsu University, No. 301 Xuefu Road Zhenjiang, Jiangsu, 212013, China; Tel: 0086-0511-88797036; E-mail: zhanghj@ujs.edu.cn
} 
The leachate recirculation system in bioreactor landfills includes vertical wells (VWs) [14 - 17], Horizontal Trenches (HTs) [18 - 21], and Drainage Blankets (DBs) [22, 23]. Waste tyre chips are commonly used to form the leachate drainage layer, but there is still controversy over whether spontaneous combustion will occur in the leachate trench [24].

There is a consensus that reducing the thickness of the tire-filled layer would help to avoid potential combustion of the tire. On the other hand, laboratory experiences demonstrated that increases in temperature from $20^{\circ} \mathrm{C}$ to $40^{\circ} \mathrm{C}$ raise considerably the $\mathrm{CH}_{4}$ generation rate, while further temperature elevation causes cessation of methanogenesis [25]. Therefore, the heat needs to be controlled for the sake of both efficiency and safety of bio-reactor landfills.

The recirculation of leachate is extensively operated under pressure in order to distribute the liquid within a limited time [26]. However, the high injection pressure may lead to a excessive pore water near the slope, which potentially results in a slope failure. Therefore, the manner of injection, namely, continuous or intermittent operation has been investigated [27] to mitigate the crisis due to pressured injection.

In the authors' preceding work [28], a spacial network of bonded whole waste tyres is assumed to be buried in municipal waste during landfill. Interfaces between tyres and waste are anticipated to make preferential flow paths for the leachate, and the connection of tyres would contribute to the enforcement of waste when subjected to any potentials of slope slide. Meanwhile, the new pattern of dispersed tyres results in a thinner drainage layer compared with the conventional tire grooves, thereby reducing the risk of underground fire. A dual-permeability mathematical model combined with the momentum balance equation is employed to simulate the flow of leachate in the bio-reactor landfill and local safety factor for slope under the condition of a pressured leachate injection. The results have proved that the spatial tire network can obviously accelerate the uniform distribution of leachate and enhance the slope stability as well.

Based on the theory of heat transfer and fluid mechanics, this study continues to establish a coupled mathematical model to investigate the interaction between leachate recirculation and heat distribution in a landfill with waste tyres embedded. The numerical simulation of both fluid and the temperature field for a simplified landfill aims to provide fundamental knowledge for the future practice of this newly proposed drainage system.

\section{METHODS}

\subsection{Leachate Flow Model}

The Richards equation is used to describe the flow of landfill leachate without tyres, whilst the dual- permeability model combines two Richard's Equations to represent the flow within the domain of waste matrix and the priority flow at the tire-waste interface separately. The two domains influence and act on each other. When using $w$, denoting the volumetric ratio of the priority domain or matrix domain with respect to the total soil volume (-), the multiple bulk soil properties are constituted by domain-specific matrix and fracture pore system properties as shown in Eq (1a-1e).

$$
\begin{aligned}
& n=w_{f} n_{f}+w_{m} n_{m} \\
& \theta=w_{f} \theta_{f}+w_{m} \theta_{m} \\
& q=w_{f} q_{f}+w_{m} q_{m} \\
& K_{s}=w_{f} K_{s f}+w_{m} K_{s m} \\
& w_{f}+w_{m}=1
\end{aligned}
$$

The two flow domains are considered to be overlapped and interacted [29] (Eq. 2 and 3)

$$
\begin{gathered}
{\left[C_{f}+S_{e f} S_{s}\right] \frac{\partial h_{f}}{\partial t}=\nabla\left[K_{f}\left(\nabla h_{f}+1\right)\right]-\frac{\Gamma_{w}}{w_{f}}} \\
{\left[C_{m}+S_{e m} S_{s}\right] \frac{\partial h_{m}}{\partial t}=\nabla\left[K_{m}\left(\nabla h_{m}+1\right)\right]+\frac{\Gamma_{w}}{w_{m}}}
\end{gathered}
$$

where the subscript $f$ indicates the preferential flow domain and the subscript $m$ indicates the matrix domain, $C$ is the 
differential water capacity $(d \theta / d h)\left(L^{-1}\right), S e$ is the effective saturation $(-)$, h is the pressure head $(L), t$ is the time $(T), K$ is the hydraulic conductivity $\left(L T^{1}\right), S s$ is the specific storage $\left(L^{-1}\right)$, and $\Gamma w$ denotes the water exchange term $\left(T^{1}\right)$ between the two domains.

The van-Genuchten function is used to describe the hydraulic properties of both the matrix and preferential flow domains [30]. The water exchange rate is assumed to be proportional to the pressure head difference between the fracture and matrix pore systems as follows [31] (Eq. 4).

$$
\Gamma_{w}=\alpha_{w}\left(h_{f}-h_{m}\right)
$$

in which $\alpha w$

$$
\alpha_{w}=\gamma_{w} \frac{\beta}{a^{2}} K_{a}
$$

Where $\beta$ is a dimensionless geometry coefficient for describing the shape of the matrix structures, $a$ is the characteristic length of the matrix structure (L), $\gamma_{w}$ is a dimensionless scaling coefficient for water absorption, and $K a$ is the relative hydraulic conductivity. A single average value of 0.4 for $\gamma_{w}$ was found to be applicable for different hydraulic properties and initial conditions [32] and the coefficient $\beta$ is equal to 3 [33]. The relative hydraulic conductivity $K a$ is calculated by averaging the hydraulic conductivities of two pore domains as $K_{a}=\left(K_{m}+K_{f}\right) / 2$ [34, 35].

\subsection{Heat Transfer Model}

According to Fourier's law and the law of conservation of energy, we can get (Eq. 6).

$$
\rho \mathrm{c} \frac{\partial \mathrm{T}}{\partial \mathrm{t}}=\nabla(\lambda \nabla \quad)-\rho \mathrm{c} \overrightarrow{\mathrm{V}} \cdot \nabla^{-}+\Phi
$$

Where,

$$
\begin{gathered}
\rho c=\left[w_{f}\left(\rho_{s} \mathrm{c}_{\mathrm{s}}+S_{e f} \rho_{l} \mathbf{c}_{l}\right)+w_{m}\left(\rho_{s} \mathrm{c}_{\mathrm{s}}+S_{e m} \rho_{l} \mathrm{c}_{l}\right)\right] \\
\overrightarrow{\mathrm{V}}=\overrightarrow{\mathrm{V}}_{\mathrm{m}}+\overrightarrow{\mathrm{V}}_{f}
\end{gathered}
$$

In the above formulas (Eq. 7), the subscript $s$ denotes the skeletal of waste, and $l$ is the pore liquid, namely the leachate in this study. $T$ is the temperature $(\mathrm{K}), \mathrm{t}$ represents time $(\mathrm{s}), c s$ is the heat capacity of solid portion of waste $\left(\mathrm{kJ} /\left(\mathrm{m}^{3} \mathrm{~K}\right)\right), c_{l}$ is the heat capacity of pore liquid, $\lambda$ is the body of the heat conduction coefficient $(\mathrm{J} /(\mathrm{ms}) \cdot \mathrm{K}), \overrightarrow{\mathrm{V}}$ is the Darcy flow rate of pore liquid (m/s), $\Phi$ is the heat source, $S e$ is the effective saturation (-).

In the landfills, the temperature rise is mainly due to waste heat caused by degradation. The instantaneous heat released by the degradation of organic waste at any time $t$ is approximated as $[36,37]$ Eq. (8).

$$
\Phi(t)=181.7 k \exp (-k t)
$$

and the coefficient $k$ is a function of temperature:

$$
k(T)= \begin{cases}0.0240 \exp \left[-0.00188(T-31.6)^{2}\right] & (T \leq 310.15 K) \\ 0.0241 \exp \left[-0.00654(T-39.1)^{2}\right] & (T>310.15 K)\end{cases}
$$

\subsection{Coupled Dual-Permeability and Thermal Model}

For the temperature-dependent dynamic viscosity coefficient, it can be calculated according to empirical formula $[8,11]($ Eq. 9).

$$
\mu=\frac{0.01775}{1+0.0337 T^{\prime}+0.000221\left(T^{\prime}\right)^{2}},
$$


Where $T$ denotes the temperature in a unit of degree (Celsius), and the resultant $\mu$ in $\mathrm{cm}^{2} / \mathrm{s}$. Taking into account the relationship between conductivity and permeability coefficient, the conductivity at current temperature can be obtained provided that the conductivity is known as listed in Table $\mathbf{1 .}$

Table 1. Summary of parameters used (at normal temperature).

\begin{tabular}{|c|c|c|c|}
\hline Symbol & Parameter & Value & Unit \\
\hline$\gamma^{a}$ & Unit weight & 5.5 & $\mathrm{kN} / \mathrm{m}^{3}$ \\
\hline$\alpha$ & Inverse of air-entry pressure & 1.4 & $1 / \mathrm{kPa}$ \\
\hline$\theta_{\mathrm{r}}$ & Residual moisture content & 0.14 & - \\
\hline$\theta_{\mathrm{s}}$ & Saturated moisture content & 0.58 & - \\
\hline$n$ & Van Genuchten fitting parameter & 1.6 & - \\
\hline$a$ & Van Genuchten fitting parameter & 0.37 & - \\
\hline$b$ & Van Genuchten fitting parameter & 0.5 & - \\
\hline$c$ & Van Genuchten fitting parameter & 0.5 & - \\
\hline$k v$ & Hydraulic conductivity & $1 \times 10^{-7}$ & $\mathrm{~m} / \mathrm{s}$ \\
\hline$K h / k v$ & Hydraulic conductivity anisotropy of MSW & - & - \\
\hline$\lambda_{\mathrm{s}}^{\mathrm{b}}$ & Thermal conductivity of waste solid & 0.216 & $\mathrm{~W} \cdot \mathrm{m}^{-1} \cdot \mathrm{K}^{-1}$ \\
\hline$c l$ & Heat capacity of Leachate & 4600.1 & $\mathrm{~kJ} /\left(\mathrm{m}^{3} \cdot \mathrm{K}\right)$ \\
\hline$c s$ & Heat capacity of waste solid & 1200.5 & $\mathrm{~kJ} /\left(\mathrm{m}^{3} \cdot \mathrm{K}\right)$ \\
\hline
\end{tabular}

$a$ The van Genuchten model parameters of MSW are after [18]

$b$ Thermal analysis parameters refers to [22]

Two Richards equations are coupled by the water exchange term, and provide the pore liquid pressure and the associated liquid velocity for the calculation of the convective flux of heat transfer. The schematic diagram of coupling approach is illustrated in Fig. (1). The detailed computational method and the verification of dual-permeability modelling refer to the authors' previous work [28].

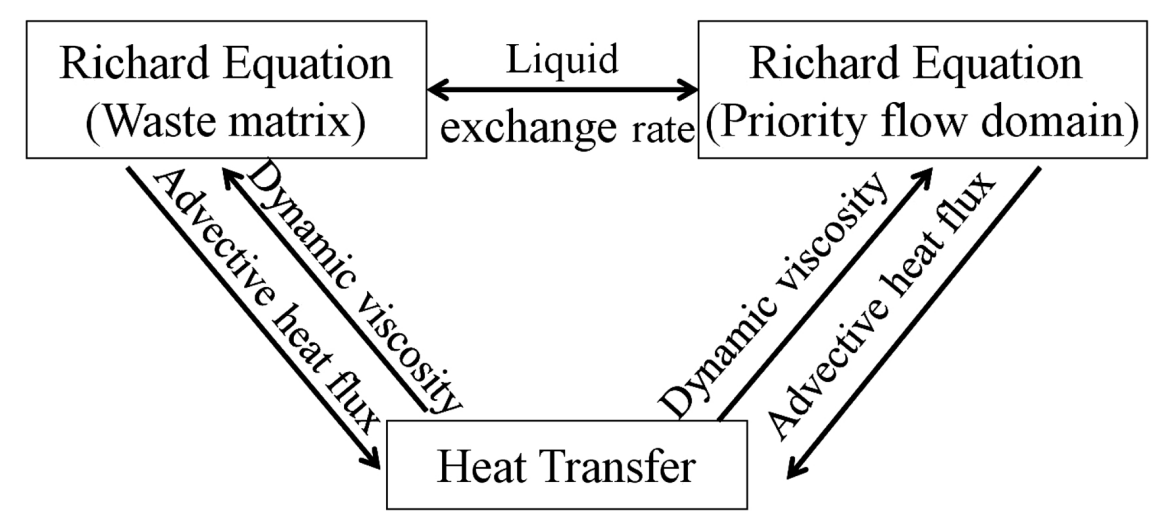

Fig. (1). Coupling method of dual-permeability flow and heat transfer models.

\section{RESULTS AND DISCUSSION}

\subsection{Application to a Landfill Profile}

The configuration of the landfill considered is analogous to the previous studies [26] as shown in Fig. (2). The leachate was injected through the horizontal trench both at a constant pressure and in a one-week on-and-off pattern, respectively. The Leachate Collection and Removal System (LCRS) is located at the bottom of the landfill and consists of sand and other substances, which has a thickness of $0.3 \mathrm{~m}$. The pore water pressure at the bottom is fixed to zero because of the drainage layer. Since the bottom is in contact with the leachate for long-term, the temperature is assumed to be $50^{\circ} \mathrm{C}$. For both leachate migration and heat transfer, the top and side slope are no-flux boundaries while the leftside is a symmetric boundary. At the top, there is no flux of leachate and the calculated annual average temperature is specified $\left(22.5^{\circ} \mathrm{C}\right.$ in the present study) to describe its contact with the atmosphere. 


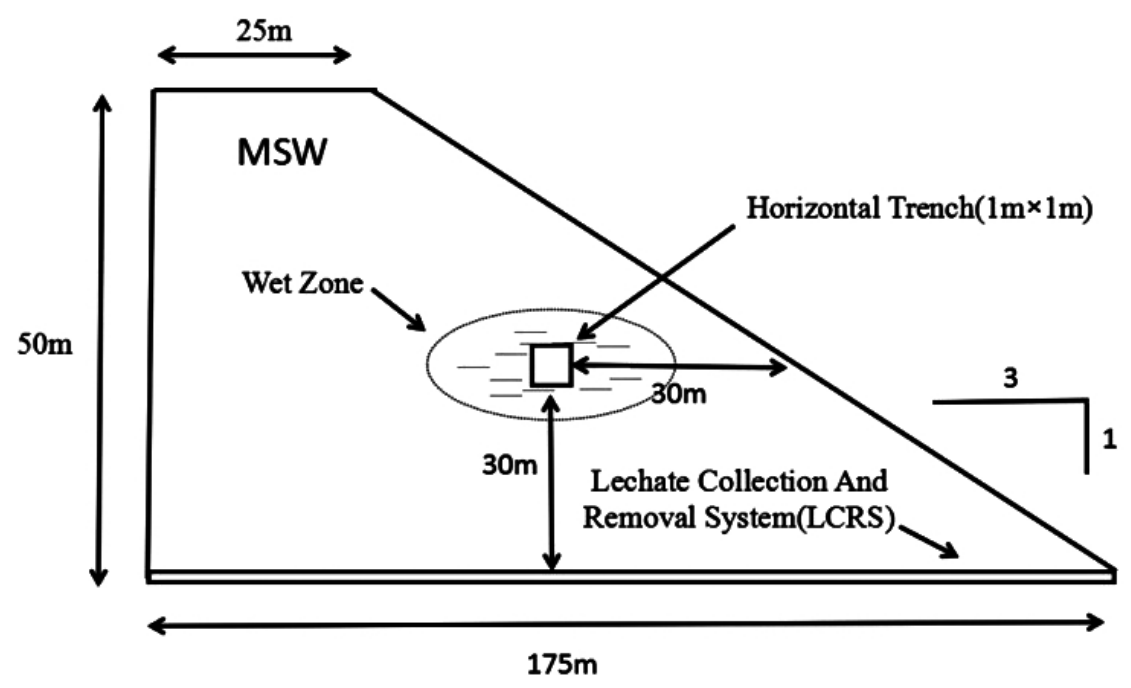

Fig. (2). Conceptual model for leachate recirculation using horizontal trench system.

Since the present study focuses on the effects of the presence of bonded tyres on the leachate flows and heat transfer, the influences of site-specific situations, such as the location of the landfill, abd the composition of waste, are represented by appropriately choosing the parameters used in the following simulations, which are listed in Table 1. In this study, the unsaturated hydraulic properties of the MSW are not varied with respect to the depth because: (1) very little published information is available on the evolution of unsaturated hydraulic properties of MSW as a function of overburden pressure; and (2) the unsaturated hydraulic properties have a relatively small impact on the key design parameters at steady flow state conditions [22].

\subsection{Effect of Heat Transfer on the Rate of Leachate Recirculation}

A base scenario without thermal effect is simulated using dual-permeability model and the flow rate, namely, the integration of leachate flux around injection trench is taken as an index to measure the effectiveness of injection. Fig. (3) demonstrates that the coupled models include the influence of varying temperature on dynamic viscosity of leachate and lead to a much higher unit flow rate. This implies the importance of considering the influence of temperature in predicting the leachate flow in landfills.

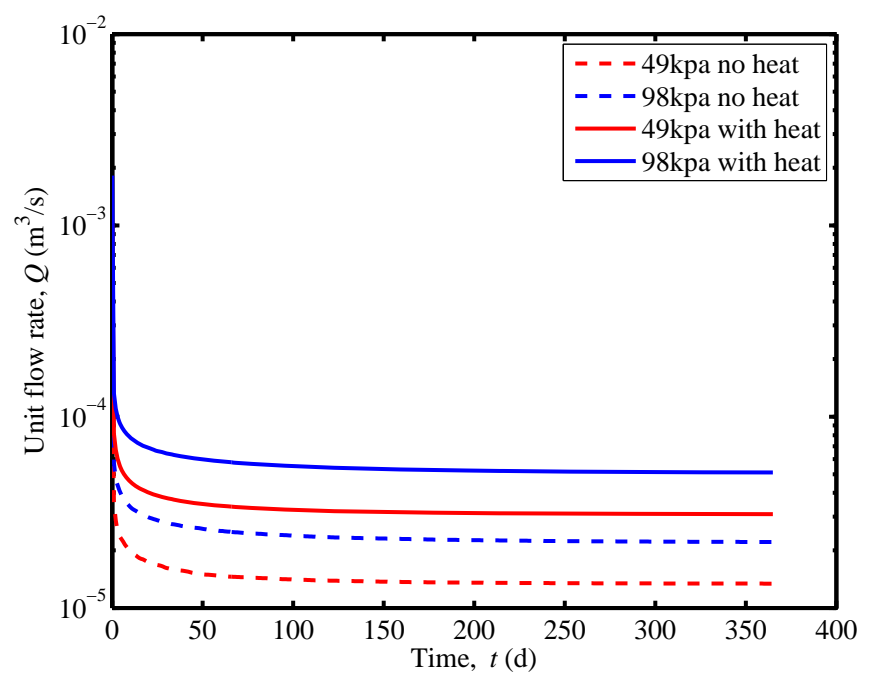

Fig. (3). Effect of temperature field on the flow rate: Red and blue colors are for injection pressure of $49 \mathrm{kPa}$ and $98 \mathrm{kPa}$, respectively.

\subsection{Effect of Tyres on the Distribution of Temperature}

Four representative points are used to probe the temperature distribution in landfill. They are located at point 1 $(15,10)$, point $2(15,25)$, point $3(15,40)$, point $4(55,25)$ and the coordinates are in the unit of meter. Fig. (4) illustrates 
that the temperature is higher in deeper location and the leachate recirculation speeds up the release of internal heat. The indicates that the convective heat flux due to the leachate flow significantly decreases the subsurface temperature, which consequently avoids too hot temperature where consequently the microbial activity would otherwise be inhibited.

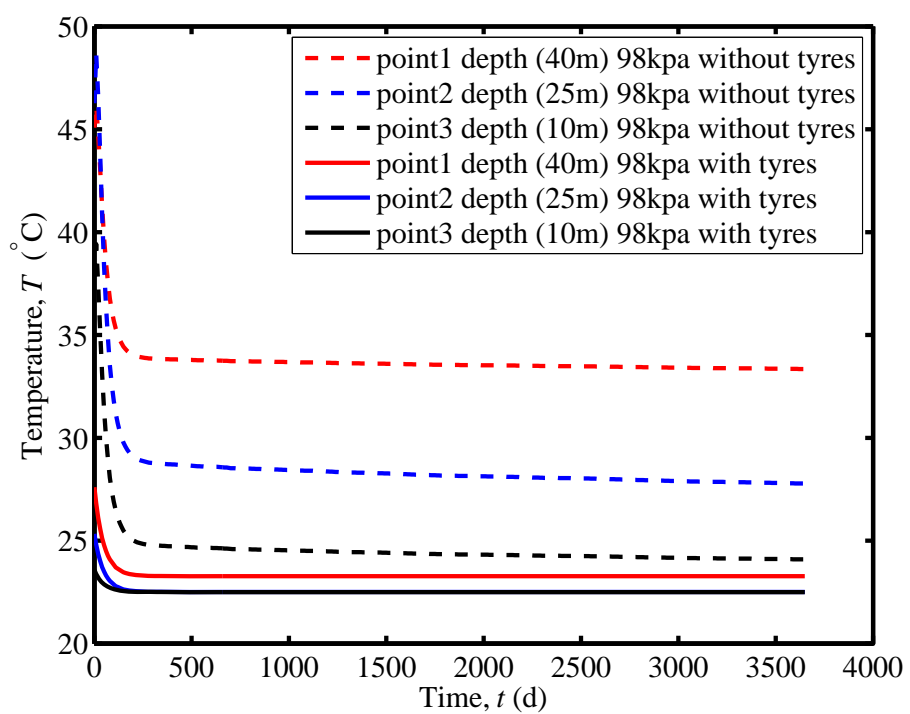

Fig. (4). Effect of leachate recirculation on the temperature field.

\subsection{Effects of Injection Method on the Distribution of Temperature}

\subsubsection{Influence of Injection Pattern}

Intermittent injection is commonly utilized to avoid excessive pore pressure and the slope failure. Here, Fig. (5) shows the temperature evolution with time for point 1,2 and 4. The temperature at shallower location experiences larger fluctuation than deeper points. The reason is probably because of the location of the trench. Whatever the depth is, the average temperature for intermittent injection is slightly higher than that for a continuous pattern. Further, the same trend is also confirmed in the contour illustrations as shown in Fig. (6).

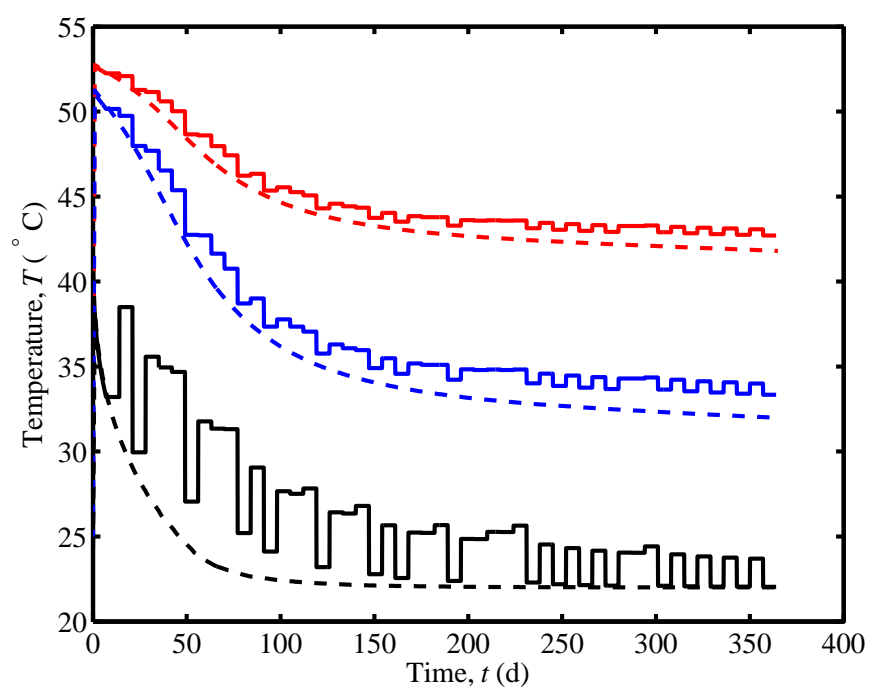

Fig. (5). Effect of intermittent leachate recirculation on the temperature field (injection pressure $=98 \mathrm{kPa}$ ): solid curves are for intermittent injection, and dotted curves are for continuous injection. 


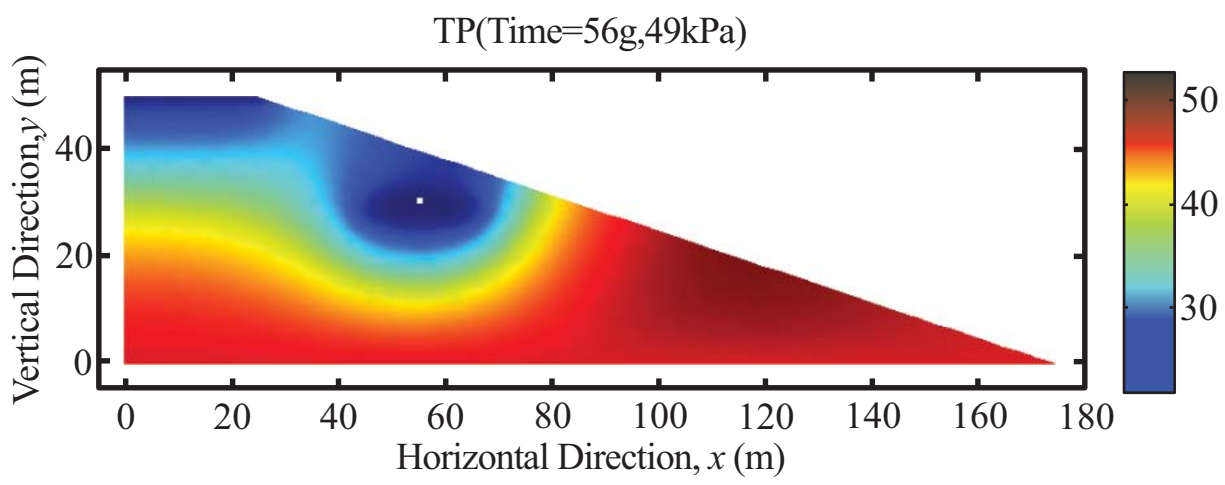

(a)

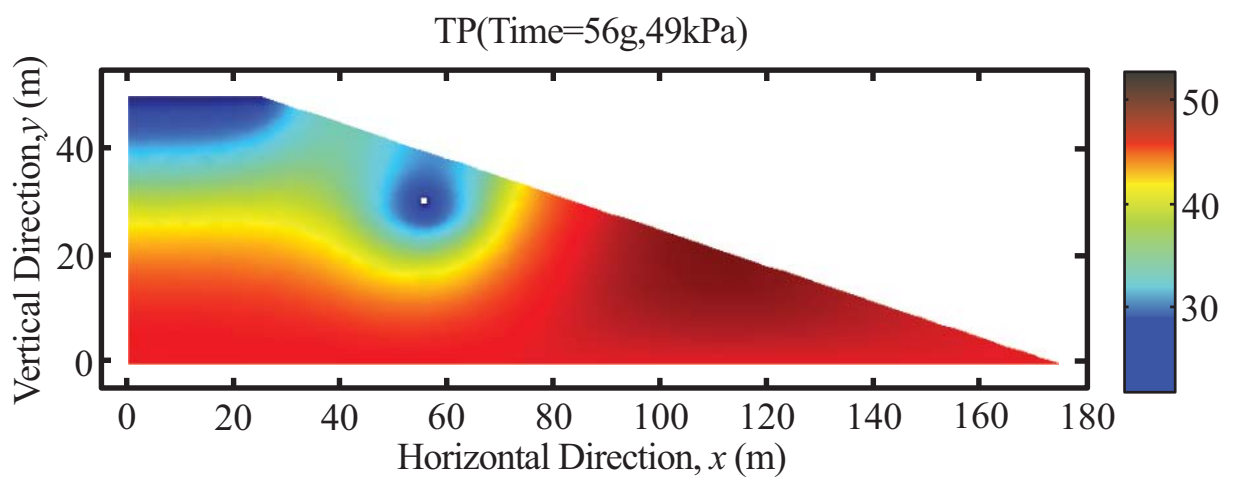

(b)

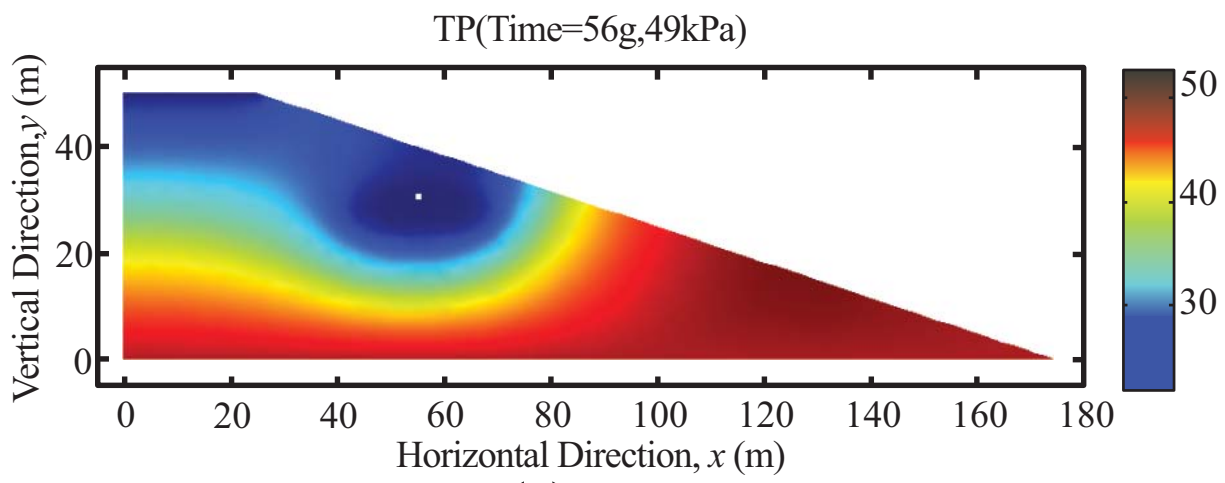

(c)

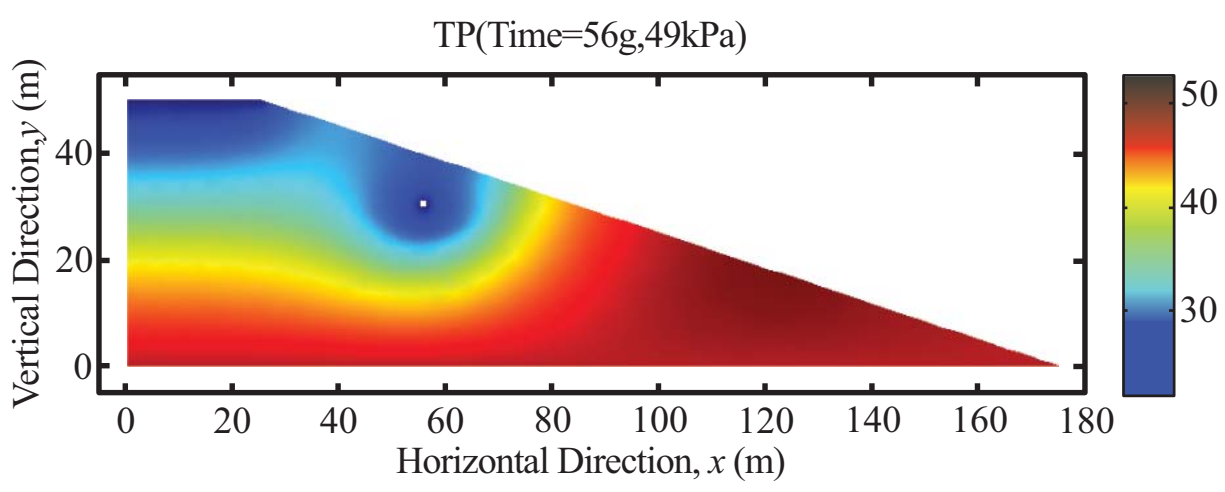

(d)

Fig. (6). Evolution of the temperature field for both continuous (left) and intermittent (right) injection: The temperature is in unit of ${ }^{\circ} \mathrm{C}$. 


\subsubsection{Influence of Injection Pressure}

Fig. (7) demonstrates that raising the injection pressure results in a lower temperature due to the quicker leachate flow and the related larger convective heat flux. However, the influence of higher injection pressure on the heat transfer is not as significant as the contribution of tyres. Therefore, the importance of waste tyres as a new leachate drainage system has been approved.

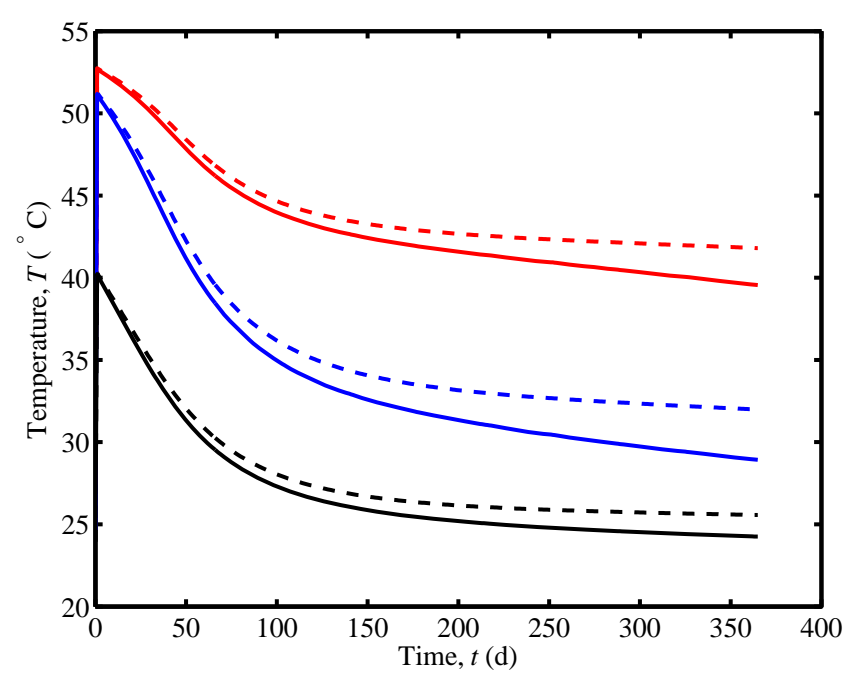

Fig. (7). Effect of injection pressure on the temperature field: solid curves are for pressure of $98 \mathrm{kPa}$, and dotted curves are for injection pressure of $49 \mathrm{kPa}$; and red, blue and black curves are for point1, point 2 and point3, respectively.

\subsection{Effect of Cooling on the Distribution of Temperature}

To account for the possible extra heat generation because of the presence of tyres, a preliminary discussion is made here in the absence of an accurate description due to the scarcity of field data. The initial temperature for the cases with tyres is designated to be $10^{\circ} \mathrm{C}$ above the normal temperature. To meet the challenge of rising temperature (which would exceed the favorite temperature range for biodegradation), cooling by adding ice to the recirculated leachate is attempted by specifying the temperature of leachate injected at $10^{\circ} \mathrm{C}$ below the normal temperature (Fig. 8). It has been found that cooling makes a considerable difference in the upper part of the landfill, but much smaller at a deeper section. Therefore, the cooling well should be placed near the hot spots. In addition, further investigations of in-situ temperature monitoring need to be performed to improve the accuracy of heat generation and the bottom temperature boundary condition for numerical simulation.

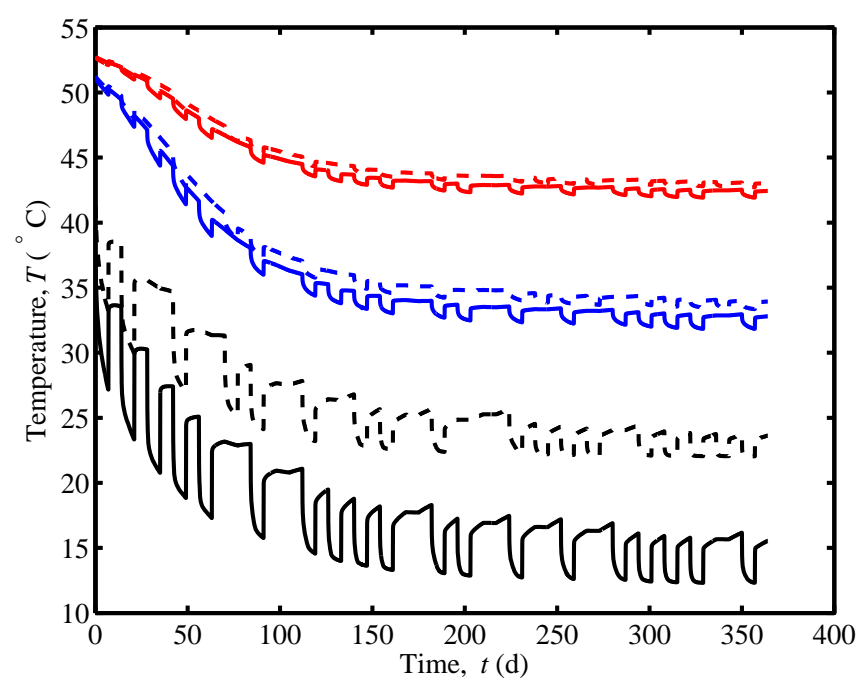

Fig. (8). Effect of cooling on the temperature field when enhanced heat generation due to tyres is considered: solid curves are for cases with cooling, and dotted curves without cooling; and red, blue and black curves are for point1, point 2 and point 4 , respectively. 


\subsection{Feasibility Discussion}

When compared with the conventional practices for a landfill which does not accept waste tyres, the additional costs of the proposed drainage system in this study arise from waste tyres baling and cooling of leachate. These two spendings are both routine for a waste tyres monofill or an inert waste landfill which assign certain cells for tyres exclusively. Regularly, a landfill operator requires that the waste tyres should be baled prior to delivery because it will be easier to handle, help save the valuable landfill space, and will have a greater potential for recovery in the future [38]. Especially for the passenger tyres, landfilling will be a better choice than recycling. Since the large capital investment required for a relatively low return, due to the high percentage of fibre and lower volumes of rubber compared with other tyres, makes it unlikely to be recycled in the short to medium term. Therefore, receiving the waste passenger tyres to construct drainage system would be an excellent choice and the fee paid by tyres collectors would help cover the expense related to tyres baling and possible cooling of leachate.

Further, the high temperature in bio-reactor landfill appears to cause methanogenic mesophile and thermophile bacteria become dormant or perish. Meanwhile, hyperthermophilic bacteria will thrive and the hot zone expands until the entire landfill is converted to a high-temperature environment, which presents many operational challenges [39]. It would be more cost-efficient if the cooling facility is integrated with a geothermal retrieval system. A case of smallscale landfill in New Hampshire, USA, has demonstrated that the payback period of the cooling system was around 7 years [39]. However, the method proposed here in this study could help alleviate the emergency for a landfill without looping in a simple manner.

Finally, floating of tyres [40] to break through the daily cover soil will help mitigate the slope stability problem, which is caused by the low conductivity of the cover soil. The cover soil was demonstrated to bring risk in the slope stability because it intercepts the leachate and causes a subsequent lateral transmission of leachate to the side slope [4]. Therefore, the improvement in safety by virtue of this new drainage system is an extra benefit besides the economic consideration.

\section{CONCLUSION}

This study coupled dual-permeability with heat transfer model to describe the non-isothermal leachate migration in a bio-reactor landfill with waste tyres embedded. The effectiveness of leachate recirculation was found to be improved by the decreasing dynamic viscosity of leachate due to the increasing temperature, which implies the importance of including the interaction between leachate seepage and heat transfer. Further, the injection method, namely, the pattern of intermittent or continuous injection and the injection pressure would influence the distribution of the internal heat in landfill. However, the presence of waste tyres net leads to a more significant lowering of temperature. Therefore, it would help release the concern of occurring of subsurface hot spots when applying this new drainage system to landfills. Additionally, cooling the leachate before injecting back at a trench near a potential hot spot could be another effective measure in avoiding the excess internal temperature. Finally, the limitations remain in this study because of the assumption of the heat generation in the presence of waste tyres and the temperature boundary condition at the bottom, which need to be resolved in further field monitoring. However, the preliminary work aims to shed light on the interaction of leachate seepage and heat transfer, and draw more attention to this alternatively new drainage system in bio-reactor landfills.

\section{CONSENT FOR PUBLICATION}

Not applicable.

\section{CONFLICT OF INTEREST}

The authors declare no conflict of interest, financial or otherwise.

\section{ACKNOWLEDGEMENTS}

This work was supported by the National Natural Science Foundation of China (Grant No. 51308259); the Foundation for Advanced Talent of Jiangsu University, PRC (Grant No. 13JDG060 and No. 14JDG023); and the sponsorship of Jiangsu Overseas Visiting Scholar Program for University Prominent Young \& Middle-aged Teachers and Presidents. 


\section{REFERENCES}

[1] D.R. Reinhart, and T.G. Townsend, Landfill bioreactor design and operation., CRC press, 1997.

[2] H.D. Sharma, and K.R. Reddy, Geoenvironmental engineering: site remediation, waste containment, and emerging waste management technologies., John Wiley \& Sons, 2004.

[3] S.R. Manzur, "Effect of leachate recirculation on methane generation of a bioreactor landfill", M.S. Thesis, University of Texas at Arlington, Arlington, TX, USA, 2010.

[4] M.A. Barlaz, R.K. Ham, and D.M. Schaefer, "Microbial, chemical and methane production characteristics of anaerobically decomposed refuse with and without leachate recycling", Waste Manag. Res., vol. 10, no. 3, pp. 257-267, 1992. [http://dx.doi.org/10.1177/0734242X9201000305]

[5] S. Chugh, W. Clarke, P. Pullammanappallil, and V. Rudolph, "Effect of recirculated leachate volume on msw degradation", Waste Manag. Res., vol. 16, pp. 564-573, 1998. [http://dx.doi.org/10.1177/0734242X9801600607]

[6] D.R. Reinhart, P.T. McCreanor, and T. Townsend, "The bioreactor landfill: Its status and future", Waste Manag. Res., vol. 20, no. 2, pp. 172-186, 2002. [http://dx.doi.org/10.1177/0734242X0202000209] [PMID: 12058823]

[7] K.R. Reddy, "Geotechnical aspects of bioreactor landfills", in Indian Geotechnical Conference 2006-Geotechnical Engineering-Indian Experience. 2006, pp.79-94.

[8] T.G. Townsend, J. Powell, P. Jain, Q. Xu, T. Tolaymat, and D. Reinhart, Sustainable practices for landfill design and operation., Springer New York, 2016.

[9] J.H. Ko, F. Yang, and Q. Xu, "The impact of compaction and leachate recirculation on waste degradation in simulated landfills", Bioresour. Technol., vol. 211, pp. 72-79, 2016. [http://dx.doi.org/10.1016/j.biortech.2016.03.070] [PMID: 27003792]

[10] J.W.F. Morris, N.C. Vasuki, J.A. Baker, and C.H. Pendleton, "Findings from long-term monitoring studies at MSW landfill facilities with leachate recirculation", Waste Manag., vol. 23, no. 7, pp. 653-666, 2003. [http://dx.doi.org/10.1016/S0956-053X(03)00098-9] [PMID: 12957160]

[11] D.T. Sponza, and O.N. Ağdăg, "Impact of leachate recirculation and recirculation volume on stabilization of municipal solid wastes in simulated anaerobic bioreactors", Process Biochem., vol. 39, pp. 2157-2165, 2004. [http://dx.doi.org/10.1016/j.procbio.2003.11.012]

[12] R.K. Giri, and K.R. Reddy, "Slope stability of bioreactor landfills during leachate injection: Effects of unsaturated hydraulic properties of municipal solid waste", Int. J. Geomech., vol. 8, pp. 144-156, 2013.

[13] C. Sawatdeenarunat, "Effects of leachate recirculation on anaerobic treatment of municipal solid waste", $3^{r d}$ International conference on geoinformation technology for natural disaster management and rehabilation, vol. vol.4, 2010pp. 448-460

[14] S.J. Feng, B.Y. Cao, X. Zhang, and H.J. Xie, "Modeling of leachate recirculation using vertical wells in bioreactor landfills", Environ. Sci. Pollut. Res. Int., vol. 22, no. 12, pp. 9067-9079, 2015. [http://dx.doi.org/10.1007/s11356-014-4045-7] [PMID: 25874416]

[15] S.J. Feng, B.Y. Cao, and H.J. Xie, "Modeling of leachate recirculation using spraying-vertical well systems in bioreactor landfills", Int. J. Geomech., vol. 17, p. 04017012, 2017. [http://dx.doi.org/10.1061/(ASCE)GM.1943-5622.0000887]

[16] M.V. Khire, M.M. Haydar, and M.M. Haydar, "Leachate recirculation using geocomposite drainage layer in engineered msw landfills", GeoFrontiers Congress, 2005pp. 1-11

[17] P. Jain, T.G. Townsend, and T.M. Tolaymat, "Steady-state design of horizontal systems for liquids addition at bioreactor landfills", Waste Manag., vol. 30, no. 12, pp. 2560-2569, 2010.

[http://dx.doi.org/10.1016/j.wasman.2010.06.024] [PMID: 20729051]

[18] K.R. Reddy, R.K. Giri, and H.S. Kulkarni, "Design of horizontal trenches for leachate recirculation in bioreactor landfills using two-phase modeling", Int. J. Environ. Waste Manag., vol. 15, pp. 347-376, 2015. [http://dx.doi.org/10.1504/IJEWM.2015.069962]

[19] G.Y.S. Chan, L.M. Chu, and M.H. Wong, "Effects of leachate recirculation on biogas production from landfill co-disposal of municipal solid waste, sewage sludge and marine sediment", Environ. Pollut., vol. 118, no. 3, pp. 393-399, 2002. [http://dx.doi.org/10.1016/S0269-7491(01)00286-X] [PMID: 12009137]

[20] K.R. Reddy, R.K. Giri, and H.S. Kulkarni, "Validation of two-phase flow model for leachate recirculation in bioreactor landfills", Waste Manag., vol. 24, pp. 1-24, 2014.

[21] M.M. Haydar, and M.V. Khire, "Leachate recirculation using horizontal trenches in bioreactor landfills", J. Geotech. Geoenviron., vol. 131, pp. 837-847, 2005.

[http://dx.doi.org/10.1061/(ASCE)1090-0241(2005)131:7(837)]

[22] K.R. Reddy, R.K. Giri, and H.S. Kulkarni, "Two-phase modeling of leachate recirculation using drainage blankets in bioreactor landfills", 
Environ. Model. Assess., vol. 20, pp. 475-490, 2015.

[http://dx.doi.org/10.1007/s10666-014-9435-1]

[23] M.M. Haydar, and M.V. Khire, "Leachate recirculation using permeable blankets in engineered landfills", J. Geotech. Geoenviron., vol. 133, pp. 360-371, 2007. [http://dx.doi.org/10.1061/(ASCE)1090-0241(2007)133:4(360)]

[24] D. Hall, D. Drury, R. Keeble, A. Morgans, and R. Wyles, "Review and investigation of deep-seated fires within landfill sites", Environment Agency, Bristol, Science Report no. SC010066, 2007.

[25] G.B. Kasali, and E. Senior, "Effects of temperature and moisture on the anaerobic digestion of refuse", J. Chem. Technol. Biotechnol., vol. 44, pp. 31-41, 1989 [http://dx.doi.org/10.1002/jetb.280440105]

[26] Q. Xu, T. Tolaymat, and T.G. Townsend, "Impact of pressurized liquids addition on landfill slope stability", J. Geotech. Geoenviron., vol. 138, pp. 472-480, 2012.

[http://dx.doi.org/10.1061/(ASCE)GT.1943-5606.0000609]

[27] N.N. Sang, S. Soda, D. Inoue, K. Sei, and M. Ike, "Effects of intermittent and continuous aeration on accelerative stabilization and microbial population dynamics in landfill bioreactors", J. Biosci. Bioeng., vol. 108, no. 4, pp. 336-343, 2009. [http://dx.doi.org/10.1016/j.jbiosc.2009.04.019] [PMID: 19716525]

[28] H. Zhang, H. Jie, D. Jeng, and H. Xu, "Effects of bonded tyres on leachate recirculation of bioreactor landfills", Open Civ. Eng. J., vol. 11, pp. $552-562,2017$. [http://dx.doi.org/10.2174/1874149501711010552]

[29] H.H. Gerke, and M.T. Van Genuchten, "A dual-porosity model for simulating the preferential movement of water and solutes in structured porous media", Water Resour. Res., vol. 29, pp. 305-319, 1993. [http://dx.doi.org/10.1029/92WR02339]

[30] G.M.T. Van, P.J. Wierenga, and G.A. O’Connor, "Mass transfer studies in sorbing porous media, 3: Experimental evaluation with 2,4,5-t trichlorophenoxyacetic acid, movement of herbicide through soil", Soil Sci. Soc. Am. J., vol. 41, pp. 1-10, 1977.

[31] C. Ray, T.R. Ellsworth, A.J. Valocchi, and C.W. Boast, "An improved dual porosity model for chemical transport in macroporous soils", J. Hydrol. (Amst.), vol. 193, pp. 270-292, 1997. [http://dx.doi.org/10.1016/S0022-1694(96)03141-1]

[32] H.H. Gerke, and M.T. Van Genuchten, "Evaluation of a first-order water transfer term for variably saturated dual-porosity flow models", Water Resour. Res., vol. 29, pp. 1225-1238, 1993. [http://dx.doi.org/10.1029/92WR02467]

[33] H.H. Gerke, and M.T. Van Genuchten, "Macroscopic representation of structural geometry for simulating water and solute movement in dualporosity media", Adv. Water Resour., vol. 19, pp. 343-357, 1996 [http://dx.doi.org/10.1016/0309-1708(96)00012-7]

[34] B. Arora, B.P. Mohanty, and J.T. McGuire, "Inverse estimation of parameters for multidomain flow models in soil columns with different macropore densities", Water Resour. Res., vol. 47, no. 4, p. WR009451, 2011 [http://dx.doi.org/10.1029/2010WR009451] [PMID: 24511165]

[35] H. Laine-Kaulio, S. Backnäs, T. Karvonen, H. Koivusalo, and J.J. McDonnell, "Lateral subsurface stormflow and solute transport in a forested hillslope: A combined measurement and modeling approach", Water Resour. Res., vol. 50, pp. 8159-8178, 2014. [http://dx.doi.org/10.1002/2014WR015381]

[36] J. Yang, "Study of temperature-chemical coupling effect in landfill disposal of household rubbish in urban area", PhD thesis, Southwest Jiaotong University, Chengdu, China, 2007.

[37] Z. Han, D. Liu, and Q. Li, "Influence of leachate recirculation on producing methane in anaerobic bioreactor", Environ. Sci. Technol., vol. 31, pp. 160-163, 2008.

[38] M. Matthews, "Investigation into the environmental, social and economic impacts of a potential banning of used tyres to landfill and of mandatory recycling of used tyres", Available from: http:// www.wasteauthority.wa.gov.au/ media/files/ documents/ impacts_tyre_policies.pdf

[39] R.J. Grillo, "Energy recycling-landfill waste heat generation and recovery", Current Sustainable/Renewable Energy Reports, vol. 1, pp. 150-156, 2014.

[40] Solid Waste Agency "The Problem with Waste tyres", Available from: https://sciswa.org/the-problem-with-waste-tyres/ Accessed: 201807-17. https://sciswa.org/the-problem-with-waste-tires/

(C) 2018 Zhang et al.

This is an open access article distributed under the terms of the Creative Commons Attribution 4.0 International Public License (CC-BY 4.0), a copy of which is available at: (https:/creativecommons.org/licenses/by/4.0/legalcode). This license permits unrestricted use, distribution, and reproduction in any medium, provided the original author and source are credited. 